\title{
CERMINAN LEGITIMASI PEMERINTAHAN ISLAM DI MASA PANDEMI
}

\author{
Oleh : Subehan Khalik \\ Subehan.khalik@uin-alauddin.ac.id \\ Fakultas Syari'ah dan Hukum UIN Alauddin Makassar
}

\begin{abstract}
\end{abstract}
This paper is an attempt to make a comparison between the Islamic government and the Jokowi government in dealing with a pandemic. By using descriptive explanatory methods to solve the problem of popular support to the government through the granting of legitimacy to power. The long journey of the Islamic government in the historical stage illustrates the solidity and expertise of the rulers to win the sympathy of the people. The Prophet's time was the beginning of the Islamic government in which the Prophet played two functions; as head of the State and holder of the highest religious authority. The two forces were united in the Prophet until his death and continued by his companions afterward, but the pattern of the Prophet's power was no longer the same as his companions. When friends hold the reins of power, they must try to win the sympathy of the people to get the legitimacy of power. That is why religious languages are always maintained for generations to maximize the function of the authorities as holders of religious authority. Facing a pandemic, two things must always unite, namely; the full authority of the government and religious authority to get the legitimacy of power. The purpose of writing is to provide input to the government to win the hearts of the majority Muslim population to gain the legitimacy of their power and be a strong grip of the government is facing the co-19 pandemic

Keywords: Legitimacy; Covid-19 Pandemic; Power; Islamic government

\section{Abstrak}

Tulisan ini adalah upaya untuk melakukan perbandingan antara pemerintahan Islam dan pemerintahan Jokowi dalam menghadapi pandemi. Dengan menggunakan metode deskriptif explanatory untuk memecahkan masalah dukungan rakyat kepada pemerintah melalui pemberian legitimasi kekuasaan. Perjalanan panjang pemerintahan Islam dalam pentas sejarah menggambarkan soliditas dan kepiawaian para penguasanya merebut simpati rakyat. Masa Nabi merupakan masa awal pemerintahan Islam dimana Nabi memerankan dua fungsi; sebagai kepala Negara dan pemegang otoritas tertinggi keagamaan. Kedua 
kekuatan bersatu pada diri Nabi hingga wafatnya dan dilanjutkan oleh sahabat sesudahnya, namun pola kekuasaan Nabi tak lagi sama dengan sahabatnya. Ketika sahabat memegang tampuk kekuasaan, mereka harus berusaha merebut simpati rakyat untuk mendapatkan legitimasi kekuasaan. Bahasa agama senantiasa dipelihara secara turun-temurun guna memaksimalkan fungsi penguasa sebagai pemegang otoritas keagamaan. Menghadapi pandemi, dua hal yang harus selalu bersatu yaitu; kekuasaan penuh pemerintah dan otoritas keagamaan untuk mendapatkan legitimasi kekuasaan. Tujuan penulisan untuk memberi masukan kepada pemerintah solusi merebut hati rakyat mayoritas muslim guna mendapatkan legitimasi kekuasaan mereka dan menjadi pegangan kuat pemerintah menghadapi pandemi covid-19

Kata Kunci : Legitimasi; Pandemi Covid-19; Kekuasaan; Pemerintahan Islam

\section{A. PENDAHULUAN}

Pandemi Corona atau lebih dikenal dengan covid-19 adalah sebuah pandemi yang melanda dunia. Ada 186 negara dari 193 negara di dunia melaporkan terjangkit penyakit ini. Dalam kamus Islam tercatat hal yang sama juga pernah melanda pada masa Nabi saw. Dan menyebabkan Nabi mengeluarkan regulasi dalam mengahadapi pandemi pada masa itu. ${ }^{1}$ Pada masa pemerintahan Khulafā al-Rāsyidūn, hal serupa juga pernah terjadi dan menyebabkan khalifah Umar bin Khațtāb terpaksa pula mengeluarkan regulasi untuk menghadapi pandemi tersebut. ${ }^{2}$ Sejarah mencatat bahwa kedua pemerintahan tersebut dapat dengan sigap menghadapi pandemi dan bersikap sangat tegas mengatur masyarakat, termasuk mobilitas mereka dari sebuah wilayah ke wilayah lainnya. Bahkan lebih jauh, pemerintahan ini mengatur regulasi daerah terpapar dan tidak terpapar dalam masa pandemi.

Masa pandemi Covid-19, rakyat dari sebuah rezim dapat secara leluasa mengukur tingkat legitimasi kekuasaan pemerintah mereka. Secara kontras cerminan atas kekuasaan dipancarkan dari sikap perilaku dan kebijakan sang penguasa dalam mengantisipasi pandemi. Tingkat kedekatan hubungan pemerintah dengan rakyatnya juga akan tercermin secara jelas dalam masa pandemi. Masa pandemi akan memperlihatkan apa yang bernama ketaatan civil (civil obedience) atau sebaliknya memamerkan pembangkangan civil (civil disobedience). Pembangkangan civil (civil disobedience) adalah sebuah teori yang

${ }^{1}$ Sitti Afifiyah, "Pandemi Corona dan Kisah Wabah Penyakit Zaman Nabi," Tagar.id untuk Indonesia (Jakarta, 2020).

${ }^{2}$ Encep Faiz, "Kisah Khulafaur Rasyidin Umar bin Khatab: Obat Penyakit Mematikan ada Pada Sabda Nabi," Mantra Sukabumi (Sukabumi, April 2020). 
mengemuka pada tahun 1854 oleh Henry David Toro dan kemudian dibantah oleh teori ketaatan civil (civil obedience) oleh Walden Two dalam buku Beyond Freedom and Dignity (1971). Bagi Ferid Muhic, pandemi covid-19 secara nyata menggiring rakyat pada sebuah razim ke sebuah arah "pegambilalihan kekuasaan total" lewat The invisible ruler (Deus absconditus - Dewa Tersembunyi). Konteks ini dapat menjadi musibah bagi rakyat atau menjadi rahmat untuk mereka sebab dalam sebuah pemerintahan terdapat komponen inti kekuasaan yaitu hubungan penguasa dengan rakyat dalam bentuk sinergi. ${ }^{3}$

Legitimasi kekuasaan dan hubungan penguasa-rakyat adalah fenomena umum dalam setiap pemerintahan. Melibatkan rakyat dalam apa yang disebut "pemerintahan", telah memaksa rezim untuk melakukan berbagai pendekatan guna memuluskan legitimasi kekuasaan mereka. Pada suku Dayak Ma'anyan ditemukan bahwa pemimpin moderen seperti Bupati dan Gubernur diberi gelar adat untuk melegitimasi kekuasaan mereka agar mereka dapat memimpin secara leluasa. Hal ini dilakukan mengingat pemimpin di kalangan suku Dayak Ma'anyan adalah tutur amau (kelas pemimpin) yang mengatur orang banyak, sehingga mereka diberi legitimasi adat untuk memuluskan rezim mereka memimpin di era moderen. Fenomena pemberian legitimasi kekuasaan oleh masyarakat adat terhadap pemimpin moderen bukan hanya pada suku Dayak Ma'anyan, melainkan dilaksanakan oleh masyarakat adat lain yang ada di Indonesia misalnya, masyarakat Bugis-Makassar, Toraja, Bali, Sumbawa, Papua dan Papua Nugini. ${ }^{4}$ Ini berarti bahwa sebuah rezim akan mengalami kesulitan jika tidak menguatkan legitimasi kekuasaan mereka dari rakyat, apatahlagi berfikir untuk menjadi rezim totaliter dalam sebuah masa pemerintahan.

Secara prinsip, Pandemi telah menghembuskan angin segar kedekatan antara pemerintah dengan rakyatnya. Namun pada sisi lain, pandemi juga berpotensi melahirkan penguasa totaliter yang menjadikan rakyat sebagai objek kendali pemerintahan dan ketika hal ini terjadi maka mustahil lagi meminta legitimasi rakyat untuk para pemimpin. Menurut TB Massa Djafar, pandemi Covid-19 berpotensi mengancam legitimasi pemerintahan saat ini dengan pertimbangan kelambanan pemerintah merespon covid-19 yang tergambar dari polemik di pemerintahan seputar siapa yang berhak menentukan sikap atas

\footnotetext{
3 Muhammad Subarkah, "Deus Abscond: Penguasa Tersembunyi dari Pandemi COVID-19," Republika.co.id (Jakarta, 2020) <https://republika.co.id/berita/qagl8k385/emdeus-abscondem-penguasatersembunyi-dari-pandemi-covid19>.

${ }^{4}$ Kisno Hadi, "Legitimasi Kekuasaan Dan Hubungan Penguasa-Rakyat Dalam Pemikiran Politik Suku Dayak Ma'anyan,” Jurnal Kawistara, 8.1 (2018), 46
} 
gerakan melawan Covid-19. ${ }^{5}$

Penelitian melakukan perbandingan legitimasi kekuasaan pada masa kekuasaan rezim Jokowi dalam menghadapi pandemi dengan kekuasaan pemerintahan Islam pada masa Nabi dan Khulafā al-Rāsyidūn sebagai manifestasi pemerintahan Islam dalam menghadapi pandemi. Metode yang digunakan adalah metode deskriptif explanatory yaitu sebuah metode kombinasi dimana metode deskriptif menjawab pertanyaan "apa" dan metode explanatory menjawab "mengapa" dan "bagaimana". Keseluruhan data dianalisis secara kulitatif interpretatif agar teori yang dihasilkan memiliki pijakan pada realitas sosial yang ada. ${ }^{6}$

\section{B. PEMERINTAHAN ISLAM VERSUS PANDEMI}

Tercatat dalam sejarah bahwa masa awal pemerintahan Islam telah terjadi duakali Pandemi, pertama terjadi masa Nabi dan kedua terjadi pada masa pemerintahan Khalifah 'Umar bin Khațāab. Khusus pada masa Nabi peristiwa pandemi kala itu terjadi bertepatan di Bulan Ramaḍān seperti halnya dialami pada masa sekarang. Kesigapan Nabi dalam mengurai benang kusut pemerintahan akibat serangan "t $t \bar{a}$ ' $u n$ " tergambar dari beberapa riwayat hadis yang mengisahkan regulasi Nabi dalam mengantisipasi pandemi yang terjadi. ${ }^{7}$ Berdasar informasi hadis yang diriwayatkan oleh Imām al-Bukhārī diberlakukan regulasi larangan masuk ke wilayah terdampak pandemi dan sebaliknya tidak keluar dari wilayah yang terserang pandemi. ${ }^{8}$ Mengindikasikan bahwa pola penanganan pandemi pada masa Nabi telah dilakukan secara maksimal dan profesional dengan menerapkan karantina wilayah sebagaimana yang kita kenal saat ini sebagai Pembatasan Sosial Berskala Besar (PSBB).

Lawrence I Conrad telah melakukan penelitian dengan penekanan pada istilah $t \bar{a}^{\prime} \bar{u} n$ dan $w a b a^{\prime}$ yang telah menimpa dunia sebelum datangnya Islam, sesudah Islam hingga menjelang abad moderen. Lawrence menekukan bahwa $t \bar{a}^{\prime} \bar{u} n$ dan $w a b a^{\prime}$ adalah dua nama yang memiliki makna sama dan dijelaskan pula bahwa para sejarawan Arab telah gagal memahami makna hakiki ță'ūn. Ibnu

${ }^{5}$ TB. Massa Djafar, “Covid 19 Ancam Legitimasi Kekuasaan Jokowi?,” telusur.co.id, 2020.

${ }^{6}$ Gumilar Rusliwa Somantri, "Memahami Metode Kualitatif,” Makara, Sosial Humaniora, 9.2 (2005), $57-65$.

${ }^{7}$ Sebaran hadis Nabi yang mengisahkan tentang wabah Ṭā'ūn pada masa Nabi dapat dilihat dalam kitab karangan A.J. Wensinck lewat pemakaian kata "țā' $\bar{u} n$ " sebagai kata kunci pencarian. Lihat selanjutnya A.J. Wensinck, Mu’jam Mufạ̣ras Li Alfāz al-Hadī̇s al-Nabawi, Juz IV (Leiden: E.J. Brill, 1936), h. 4.

${ }^{8}$ Abū 'Abdillāh Muḥammad bin Ismā’̄il al-Bukhārī, Al-Jāmi' al-Ṣaḥ̄ḥ Li Abī 'Abdillāh Muḥammad bin Ismā'̄̄l al-Bukhārī (Kairo: Maktabah al-Salafiyah, 1980), h. 41. 
Hajar al-'Asqalānī menyatakan bahwa sejarawan Arab sebelumnya telah salah menuliskan pengertian $t \bar{a}^{\prime} \bar{u} n$ sesungguhnya, sehingga terkadang banjir, tanah longsor dan bencana alam lainnya dimasukkan dalam kategori $t a^{\prime} \bar{u} n$. Lawrence kemudian mengunci penjelasannya dengan menyatakan bahwa ada kemungkinan yang dimaksud dengan $t \bar{a}^{\prime} \bar{u} n$ adalah pandemi pes atau black-death yang telah banyak menelan korban di Eropah. ${ }^{9}$

Kesimpulan Lawrence juga menjadi titik temu mengenai pandemi yang melanda pada pada masa Nabi sesungguhnya tidaklah berhenti hingga masa Khalifah 'Umar bin Khaț̣āb dan masa sesudahnya, bahkan ada indikasi yang menunjukkan bahwa pandemi tersebut terus berlansung dalam kurun waktu yang sangat panjang dan serangan paling mematikan dan lebih massif terjadi pada masa kekuasaan kekhilafahan terakhir Islam di Turki. Pemerintahan Islam setidaknya harus menahan dua pandemi yang terjadi di dunia dengan laju kematian tinggi dalam tiga kurun waktu; pertama black death pada abad keempat, wabah justianus (pes, kolera) pada abad ke enam dan wabah Bombay pada abad ke sembilan belas. ${ }^{10}$

Kekaisaran Sassanid tampak tak berkutik menghadapi pandemi black-death dan Justianus dan berakhir dengan sangat tragis pada kehancuran pemerintahan mereka. Hal serupa juga terjadi dengan pemerintahan Islam pada masa Bani Umayyah, meski hanya mengalami wabah endemik namun implikasi serangan tersebut telah membawa perlambatan pada laju tingkat populasi dan peradaban di wilayah Suriah dan Irak. ${ }^{11}$ Ini berarti bahwa pandemi telah menjadi momok menakutkan bagi pemerintahan sebuah bangsa dan mungkin juga dapat menjadi titik awal kehancuran mereka dan peluang mereka terhapus dari peta kekuasaan.

Kesigapan dalam mengelola pandemi sebagai peluang untuk mempertahankan kekuasaan atau mengembangkannya dalam spektrum yang lebih besar yaitu memper tahankan sebuah bangsa dari kepunahan adalah dua catatan penting bagi sebuah rezim dalam mengelola pandemi. Pilihan yang amat sulit dan membutuhkan figur kenega rawanan untuk memecahkan masalah tersebut secara bersamaan. Prinsipnya, ketika figur penguasa tertinggi memfokuskan perhatian mereka pada pilihan kedua, maka pilihan pertama secara otomatis mengikut.

\footnotetext{
${ }^{9}$ Lawrence I Conrad, “Ta' Un and W' Aba '," Social History, 25.3 (2013), 268-307.

${ }^{10}$ Michael W. Dols, "The Second Plague Pandemic And Its Recurrences In The Middle East: 13471894," Journal Of Economic and Social History of the Orient, 22.2 (1979), 162-89.

${ }^{11}$ American Oriental Society, "Plague in Early Islamic History Author ( s ): Michael W. Dols Published by: American Oriental Society Stable URL: http://www.jstor.org/stable/600071 . PLAGUE IN EARLY ISLAMIC HISTORY," 94.3 (2013), 371-83.
} 
Kemampuan pemerintahan Islam dalam mitigasi bencana turut mendukung legitimasi kekuasaan. Rakyat yang terdidik dengan pola hidup sehat berdasarkan ajaran Nabi menciptakan kondisi kondusif. Pola hidup sehat dan bersih baik diri maupun lingkungan membuat rakyat siap menghadapi wabah pandemi. Meski wabah melanda, pemerintahan Islam seolah tak bergeming menghadapinya. Bahkan ada kecenderungan pemerintahan Islam memiliki kemampuan lebih dalam menaklukkan Negara-negara yang melemah akibat serangan wabah. ${ }^{12}$ Kekaisaran besar selevel Sassanid mampu dilumat dengan mudah oleh pemerintahan Islam adalah bukti jika legitimasi kekuasaan merupakan energy inti dalam mengelola bangsa. Legitimasi kekuasaan menempatkan rakyat sebagai mitra kekuasaan turut serta berperan melawan pandemi melalui gerakan social distancing yang merupakan garda terdepan mitigasi bencana wabah. ${ }^{13}$

Pemerintahan Islam pada masa awal dan masa 'Umar bin Khațtāb telah mampu mengelola konflik pandemi menjadi peluang untuk memperkuat legitimasi kekuasaan secara elegan. Faktor posisi Nabi sebagai kepala agama dan kepala pemerintahan menjadi modal dasar mengembangkan potensi kekuasaan pemerintahan. Berbeda dengan Era modern, kekuasaan pemerintahan tidak lagi menjadi penguasa terhadap agama sehingga legitimasi kekuasaan pemerintah dalam sector keagamaan memberi kontribusi yang amat kecil. Akibatnya, pemerintah seolah kerdil menghadap masalah-masalah keagamaan bahkan di Negara sekuler pun, kekuasaan pemerintah dalam sektor keagamaan menjadi ujian legitimasi kekuasaan. Turki merupakan sampel terbaik mengenai ujian legitimasi kekuasaan pemerintah dalam era pandemi. Lembaga keagamaan bernama "Diyanet" harus cepat dan sensitive menyikapi perilaku sosial masyarakat Turki menghadapi pandemi. Meski terkenal sebagai Negara Sekuler, Turki ternyata meletakkan kepekaan terhadap masalah keagamaan dalam daftar utama kebijakan pemerintahan. Tentu sikap dan perilaku pemerintah Turki bukan tak berdasar. Sikap peka terhadap masalah keagamaan sangat disadari oleh pemerintahan Erdogan sebagai potensi terpendam dari legitimasi kekuasaan dari rakyat. Ketika pemerintahan Turki terselamatkan dari upaya kudeta, peran legitimasi kekuasaan dari rakyat dalam bentuk gerakan keagamaan terlihat kontras. Itu sebabnya ketika pandemi melanda Turki, maka pemeritah menjadi sokoguru "Diyanet" untuk menyiapkan segala macam pertimbangan

12 Hamid Ashraf et al., "Fighting pandemics: Inspiration from Islam," JPMA. The Journal of the Pakistan Medical Association, 70 3).5 (2020), S152-56 <https://doi.org/10.5455/JPMA.34>.

${ }^{13}$ Ashraf et al. "Fighting pandemics: Inspiration from Islam," 
menghadapi pandemi, misalnya anjuran untuk tidak mendatangi masjid ketika sakit atau mengosongkan masjid untuk sementara waktu dalam masa lokdown. ${ }^{14}$

Pengalaman pemerintah Turki dalam mengelola legitimasi kekuasaan di sektor keagamaan seyogyanya diikuti oleh Negara demokrasi berpenduduk muslim mayoritas. Rakyat mayoritas beragama Islam membutuhkan kebijakan pemerintah yang berkaitan dengan kebutuhan spiritual, apatahlagi dalam kondisi pandemi ternyata banyak sektor kehidupan seorang muslim harus berhadaphadapan dengan kekuasaan pemerintah. Kegagalam pemerintah mengelola sector spiritual, akan memicu penarikan legitimasi pemerintah oleh rakyat. Tak heran jika dalam masa pandemi, ancaman disintegritas muncul menjadi momok menakutkan bagi penguasa. Itu sebabnya, Indonesia sebagai salah satu Negara demokrasi memilih sikap untuk mengelola kekuasaan keagamaan yang dilegitimasikan kepada Majelis Ulama Indonesia (MUI) untuk dikelola secara bijak dan maksimal, meskipun dalam beberapa kasus ditemukan perbedaan kehendak pemerintah dengan keinginan pemuka agama di MUI. Ketika itu terjadi, maka ada baiknya jika legitimasi kekuasaan MUI dalam masalah keagamaan tidak diusik oleh penguasa guna menghindari disentegrasi dan konflik horizontal. ${ }^{15}$

\section{PEMERINTAHAN JOKOWI VERSUS PANDEMI}

Disinyalir bahwa Covid-19 pertamakali menyerang Indonesia dan diumumkan ke public oleh Presiden Jokowi pada 2 Maret 2020, ${ }^{16}$ meski sebelumnya media massa telah ramai melaporkan serangan serupa terhadap Kota Wuhan. ${ }^{17}$ Ini berarti ada transisi waktu yang cukup lama bagi pemerintahan Jokowi untuk mempersiapkan diri menghadapi pandemi covid-19. Efektifitas transisi waktu menghadapi pandemi covid-19 tentu tidak bisa menjadi alat ukur untuk menguji seberapa sigap pemerintahan Jokowi, namun bagi kalangan tertentu penilaian kesigapan itu mulai dinilai ketika pemerintah telah tanggap terhadap pandemi yang terjadi. Intinya, rakyat menjadi penonton yang akan

${ }^{14}$ Oğuz Alyanak, "Faith, Politics and the COVID-19 Pandemic: The Turkish Response," Medical Anthropology: Cross Cultural Studies in Health and Illness, 00.00 (2020), 1-2 <https://doi.org/10.1080/01459740.2020.1745482>.

${ }^{15}$ Muhamad Agus Mushodiq dan Ali Imron, "Peran Majelis Ulama Indonesia Dalam Mitigasi Pandemi Covid-19 (Tinjauan Tindakan Sosial dan Dominasi Kekuasaan Max Weber)," SALAM: Jurnal Sosial dan Budaya Syar-i, 7.5 (2020) <https://doi.org/10.15408/sjsbs.v7i5.15315>.

16 Sapto Andika Candra/ Red: Andri Saubani, "Jokowi Umumkan Dua Kasus Pertama Positif Corona di Indonesia," Republika.co.id, 2020.

${ }^{17}$ Fino Yurio Kristo, "Pejabat China: COVID-19 Sudah Lama Ada, Bukan dari Pasar Wuhan," Detik.com, 2020. 
menilai seberapa layak permainan kekuasaan Jokowi dan jajaran dapat menarik mereka untuk memberi legitimasi kekuasaan, ataukah mencabut legitimasi tersebut.

Upaya pemerintahan Jokowi untuk menguatkan legitimasi kekuasaan dengan menarik simpati rakyat telah dilaksanakan secara maksimal. Pelibatan pemegang autoritas keagamaan melalui dua ormas terbesar Islam; NU dan Muhammadiyah, adalah bukti bahwa pemerintahan Jokowi tak ingin kehilangan otoritas dan legitimasi kekuasaan dari rakyat. Sebagai pengendali tertinggi atas kekuasaan, Jokowi sangat faham bahwa otoritas keagamaan mutlak dibutuhkan melawan pandemi covid-19. Sisi yang menjadi pertimbangan adalah, bagaimana memberikan pemahaman kepada rakyat pemegang otoritas kekuasaan sesungguhnya. Membangun pemahaman bahwa akan ada kebijakan pemerintah yang membatasi interaksi di tempat beribadah dan kegiatan keagamaan lainnya harus mereka lakukan sebagai upaya melawan covid-19. Tentu saja sentakan atas pembatasan ruang lingkup beragama menjadikan rakyat terdistorsi dan berakibat pada penolakan sebagian kalangan dan penerimaan atas sikap pemerintah di sisi lainnya. ${ }^{18}$

Pemeritah harus ekstra hati-hati dalam melakukan komunikasi politik kepada rakyat guna menghindari distorsi. Majelis Ulama Indonesia selaku pemegang autoritas keagamaan resmi pemerintah dituntut semakian kreatif dalam melahirkan diksi kebera gamaan di masa pandemi. Majelis Ulama Indonesia (MUI) dituntut menjadi garda terdepan dalam membangun kesadaran umat melakukan mitigasi bencana selevel pandemi. Agar edukasi dapat membuahkan kesadaran rakyat sebagai pemberi legitimasi untuk ikut serta dalam gerakan secara sadar dan bertanggungjawab. Nilai kesadaran masyarakat ikut serta dalam gerakan sadar bencana menyebabkan MUI menjadi titik sentral penentu keberhasilan pemerintahan Jokowi melawan Covid-19. Fatwa-fatwa yang menunjang kearah kesadaran rakyat mengikuti protokol penanganan dan menghinari covid-19 haruslah dikemas dalam bahasa agama yang apik, misalnya; "Makruh bagi rakyat untuk berkegiatan di dalam kerumunan tanpa menggunakan masker" atau bahkan meningkatkan fatwa tersebut ke arah pengharaman, demi menjaga kemaslahatan atas jiwa. Upaya MUI melakukan talfíq manhaji berupa penetapan hukum melalui lintas mazhab. Upaya progresif MUI dalam menopang pemerintah untuk mendapatkan legitimasi rakyat melalui

\footnotetext{
18 Dadang Darmawan et al., "Sikap Keberagamaan Masyarakat Menghadapi Wabah COVID-19," Religious: Jurnal Studi Agama-Agama dan Lintas Budaya, 4.2 (2020), 115-24 <https://doi.org/10.15575/rjsalb.v4i2.8596>.
} 
otoritas keagamaan tentu saja akan diterima secara terbuka oleh ormas-ormas yang menjadi mitra MUI dan menyebabkan fatwa-fatwanya lebih akomodatif kepada seluruh golongan. ${ }^{19}$

Amat disayangkan bahwa pelibatan MUI dalam upaya menguatkan legitimasi pemerintah dalam melawan pandemi terkesan parsial. MUI tidaklah menjadi tim inti dalam komite percepatan pemberantasan melawan covid-19. Mungkin di sisi inilah pemerintah sadar bahwa legitimasi kekuasaan di sisi keagamaan wajib mereka bangun untuk melawan pandemi covid-19.. Bahasa agama menjadi bahasa efektif penyampai pesan moral bagi rakyat untuk ikut serta melakukan gerakan perlawanan terhadap pandemi covid-19 minimal untuk keselamatan pribadi. Aneh, jika kemudian Negara sekuler selevel Turki memaksimalkan fungsi otoritas lembaga keagamaan dalam melawan pandemi covid-19. Padahal MUI telah melakukan upaya maksimal dengan pendekatan bahasa fatwa untuk merayu rakyat agar memaksimalkan peran mereka melawan pandemi covid-19. ${ }^{20}$

Letupan perlawanan dari kebijakan pemerintahan melakukan Pembatasan Sosial Berskala Besar (PSBB) yang berimplikasi pada penutupan tempat-tempat ibadah termasuk masjid. Menjadi bahan evaluasi untuk mengukur efektifitas komunikasi politik pemerintah dalam masa pandemi. MUI sebagai pemegang otoritas keagamaan tertinggi pemerintah menjadi ikon utama menyelesaikan bahasa agama dalam masa pendemi. Kesan bahwa penutupan masjid sebagai upaya melemahkan iman rakyat oleh pemerintah seharusnya telah dirampungkan dengan kampanye atau propaganda positif melawan kesenjangan informasi di era pendemi. Tentu saja, peran sebagai regulator informasi keagamaan pemerintah amat kurang jika MUI ditempatkan sebagai sub sektor projek mercusuar melawan covid-19. Malah terkesan bahwa MUI menjadi alat pemerintah untuk menguatkan legitimasi kekuasaan dengan slogan ajakan bagi ormas untuk mendukung pemerintah melawan corona. ${ }^{21}$

Apapun pilihan dan sikap pemerintah dalam menempatkan MUI sebagai otoritas keagamaan tetap perlu didorong untuk lebih menempatkan MUI dalam peran inti mendapatkan legitimasi kekuasaan dari rakyat untuk menopang pemerintahan. MUI selaku otoritas keagamaan secara teoritik dibutuhkan untuk mejadi pionir pergerakan massif rakyat dalam menopang pemerintah melawan pandemi covid-19. Bahasa agama merupakan bahasa sederhana yang mudah dicerna dan berisi beban psikologis untuk dilaksanakan. Janji pahala dan dosa

\footnotetext{
${ }^{19}$ Mushodiq dan Imron.

${ }^{20}$ Nanda Perdana, "Berikut 9 Poin Fatwa MUI Sikapi Wabah Virus Corona di Indonesia," Merdeka.com (Jakarta, 2020).
}

21 “MUI Ajak Ormas Islam Dukung Kebijakan Jokowi Atasi Corona,” CNN Indonesia, 2020. 
merupakan bahasa eskatologis agama yang menyebabkan penganutnya patuh tanpa tawaran. Ketika sang otoritas menyampaikan bahasa perlawanan terhadap pandemi dengan rumusan pesan agama, maka rakyat akan mengikut dengan senang hati. Atau dengan kata lain, memanfaatkan MUI dalam menggapai legitimasi kekuasaan dari rakyat di era pandemi adalah upaya ekonomis menyampaikan pesan-pesan perlawanan terhadap covid-19 dan dipastikan memiliki pengaruh yang mengakar.

MUI di lain sisi dituntut untuk kian mengembangkan potensi diri guna menopang eksistensi dan tingkat penerimaan rakyat terhadap fatwa-fatwa mereka. MUI seyogyanya memiliki tim IT yang kuat dalam penyampaian pesan agama, begitupula dalam megelola potensi fatwa agar bersifat komulatif. Hal ini telah disampaikan dalam karya terdahulu dalam studi kritis MUI terhadap pemanfaatan media social dalam bermuamalah dimana MUI hanya focus pada medsos untuk muamalah, padahal secara faktual pengguna internet ternyata lebih dominan untuk jual-beli, namun hal tersebut seolah alfa untuk diatur. Mungkin semangat fatwa ketika itu adalah kebutuhan politik dalam masa kampanye capres dan wapres lewat medsos yang cenderung mulai brutal. ${ }^{22}$

Indikator kekosongan legitimasi kekuasaan pemerintahan Jokowi amat terasa ketika Pembatasan Sosial Berskala Besar mulai diterapkan dan masjidmasjid mulai ditutup secara keseluruhan. Pilihan pemerintah melakukan penutupan masjid secara keseluruhan berbeda dengan fatwa MUI yang masih membolehkan daerah-daerah hijau untuk melakukan aktifitas di masjid. ${ }^{23}$ Beberapa daerah melakukan penolakan, bahkan media sosial mulai ramai dengan tanggapan sinis terhadap pilihan pemerintah yang tidak populis. Perbincangan bahkan dikaitkan dengan rezim berkuasa yang dianggap sebagai kelompok nasionalis anti agama. Ketua Dewan Pertimbangan MUI Din Syamsuddin ikut bersuara lantang melakukan kritik terhadap inkonsistensi pemerintah dalam penutupan masjid terkait fatwa MUI. ${ }^{24}$

Mekanisme penutupan masjid oleh pemerintah dan regulasi penutupan masjid oleh MUI, tampak berbeda dari segi implementasi. Sikap pemerintah seharusnya sangat berhati-hati dengan fatwa MUI mengenai penutupan masjid sebab telah mempertimbangkan azas mașlahat. Pemerintah sebagai pemegang

\footnotetext{
${ }^{22}$ Subehan Khalik Umar, "Studi Kritis Terhadap Respon Majelis Ulama Indonesia (Mui) Tentang Pemanfaatan Media Sosial Dalam Bermuamalah,” Al Daulah: Jurnal Hukum Pidana dan Ketatanegaraan, 7.1 (2018), 39-50<https://doi.org/10.24252/ad.v7i1.5463>.

${ }^{23}$ Rayful Mudassir, "MUI Kritik Pemerintah Soal Penutupan Masjid,” Bisnis.com, 2020.

${ }^{24}$ Nur Azizah, "Mahfud Tanggapi Keluhan MUI Terkait Penutupan Masjid,” medcom.id, 2020. 
tampuk tertinggi kekuasaan harus mempertimbangkan legitimasi kekuasaan ketika memilih untuk bersikap dalam menentukan penutupan masjid di masa pandemi. MUI sebagai pemegang otoritas keagamaan menjadi corong pemerintah menyuarakan dakwah tentang penutupan masjid dan hal-hal lain yang mengelilingi masalah tersebut. Tentu saja MUI akan sangat berhati-hati menyusun fatwa sebab MUI terdiri dari ulama-ulama kawakan yang alim. Disharmoni antara pemerintah dan MUI dalam bersikap, juga merupakan sebuah pertunjukan teatrikal kekuasaan dalam berbangsa. Kedua komponen menjadi inti utama kekuasaan Negara, meski MUI pada dasarnya hanya menduduki posisi tidak formal, namun dapat mendukung legitimasi kekuasaan pemerintah secara berkelanjutan.

Majelis Ulama Indonesia dituntut pula untuk semakin profesional memahami sikap pemerintah menghadapi pandemi. Komunikasi dua arah pemerintah dengan MUI menjadi jalan keluar dan iklim kondusif dalam pemerintahan. Legitimasi kekuasaan dari rakyat tentu menjadi idaman pemerintah saat ini dan MUI selaku pemegang otoritas keagamaan memegang kunci keberhasilan legitimasi dari rakyat yang mayoritas muslim. Meski Indonesia bukan Negara agama, perolehan simpati rakyat yang mayoritas beragama Islam akan memudahkan pemerintah menarik simpati untuk mendapatkan legitimasi kekuasaan.

\section{PANDEMI VERSUS LEGITIMASI}

Sebagaian kalangan mungkin memaknai bahwa kehadiran agama pada sebuah Negara adalah kesalahan. Fikiran seperti ini telah dimanipulasi secara terstruktur oleh penjelmaan pemahaman terhadap makna sekularisme yang bias. Bagi Akeel Bilgrami, sekularisme merupakan penamaan dari gerakan politik dalam melawan hegemoni agama dan bukanlah sebuah upaya untuk memisah kan agama dengan Negara. Sekularisme tidak bertujuan menghapus peran agama, namun berupaya untuk menetralisir peran agama yang telah overkapacity dalam kekuasaan di Masyarakat Eropa. Itu sebabnya, sekularisme menjadi redaman terhadap kekuasaan masksimum agama dan menempatkannya dalam sebuah posisi netral, agar Negara dan agama dapat saling beriringan. ${ }^{25}$

Bagi kalangan yang memilih mazhab sekularisme dalam mengelolah Negara, maka perimbangan pemahaman yang dikemukakan oleh Akeel Bilgrami bermanfaat untuk mereduksi pemahaman yang berlebihan terhadap kontradiksi agama dalam masyarakat. Teori sekularisme Akeel dapat menjadi konteks baru dalam memaknai kehadiran sekularisme. Tanpa disadari telah terjadi kesalahan

${ }^{25}$ Akeel Bilgrami, Secularism, Identity, and Enchantment, 1st ed. (London: Harvard University Press, 
persepsi terhadap konsep sekularisme yang menjadi tonggak utama terciptanya iklim demokratis dalam sebuah Negara.

Beberapa Negara dengan penduduk mayoritas muslim memiliki keunikan dalam menerapkan sekularisme dalam bernegara. Pengaruh dan latar belakang sejarah pemerintahan Islam yang memadukan agama dan Negara tak dapat hilang dari mimpi dan harapan warga Negara. Akibatnya, terjadi pergumulan berkepanjangan antara sekularisme dengan system pemerintahan Islam. Pertarungan panjang melahirkan sintesa dan penerimaan warga Negara muslim terhadap pola bernegara ala sekuler, namun tak sepenuhnya menghilang kan peranan pemuka agama dalam mengatur tatanan hidup mereka. Setidaknya, sintesa bernegara seperti ini dapat disaksikan pada Negara muslim mayoritas seperti Turki, Mesir, Indonesia, dan beberapa Negara sekuler lainnya. Turki ternyata tak sepenuhnya membenamkan ideology sekularisme dalam kehidupan bernegara meski Turki menjadi Negara paling terpukul dengan kehadiran sekularisme pasca kejatuhan pemerintahan Islam. Pada akhirnya pada pemikir menempatkan agama dan sekularisme bukan lagi sebagai sebuah pertentangan sebab para ahli ilmu sosial telah mengamati bahwa kedua hal ini cenderung tidak bertentangan. ${ }^{26}$ Teori Rawls tentang sekularisme dan agama dalam "overlapping con-Sensus" telah menemparkan sekularisme dan agama saling berdampingan, bahkan Charles Taylor lebih ekstrim lagi dalam memaknai terori "overlapping" dengan menyatakan bahwa teori tersebut adalah cara hidup berdampingan antara sekularisme dengan agama. ${ }^{27}$

Indonesia sebagai Negara dengan mayoritas penduduk muslim tidaklah mungkin meninggalkan legitimasi pendudk muslim dalam menguatkan pemerintahan. Hampir seluruh partai nasionalis mendudukkan badan atau lembaga yang akan mengurai harmoni bernegara dengan kaum muslimin untuk kepentingan politik mereka. Sebagai contoh di tubuh Partai Demokrasi Perjuangan ditemukan BAMUSI (Baitul Muslimin Idonesia). Organisasi sayap PDI $P$ ini menghimpun kader muslim dalam partai untuk berkiprah dalam jalur keagamaan. Tak dipungkiri bahwa BAMUSI menjadi perwujudan dari keinginan partai besar sekaliber PDI P untuk mendapatkan legitimasi kekuasaan sebab mereka saat ini menjadi Partai Penguasa. ${ }^{28}$ Pandemi dengan segala kerusakan yang ditimbulkannya, telah membawa sebuah ancaman baru terhadap Indonesia. Pandemi secara nyata menggerus cadangan devisa nasional secara signifikan, melesukan ekonomi, bahkan mengantarkan Indonesia ke depan gerbang resesi. ${ }^{29}$

\footnotetext{
${ }^{26}$ Ahmet T Kuru, Secularism and State Policies Toward Religion The United States, France, and Turkey, ed. oleh Kenneth D. Wald David C. Leege, 1st ed. (New York: Cambridge University Press, 2009), h. 1-5.

${ }^{27}$ Kuru.

${ }^{28}$ Teguh Firmansyah, "No Title," Republika.co.id, 2020 <https://republika.co.id/berita/qcj7fa377/ bamusi-pdip-bukan-komunis>.

${ }^{29}$ Elsa Catriana, "RI Dinilai Perlu Waspada Potensi Resesi Ekonomi Akibat Corona,” Kompas.com (Jakarta, 2020) <https://money.kompas.com/read/2020/03/19/162019026/ri-dinilai-perlu-waspada-potensiresesi-ekonomi-akibat-corona>.
} 
Pengaruh negative Covid secara lansung berhadapn dengan legitimasi rakyat yang sedang berjuang menghadapi himpitan ekonomi akibat Covid. Kondisi buruk dalam ekonomi yang menyeret perpolitikan perlu mendapatkan perhatian khusus dan rezim Jokowi harus memiliki kekuatan ekstra sebagaimana rezim dalam pemerintahan Islam merawat legitimasi rakyat. Rezim dalam pemerintahan Islam tahu persis memahami rakyat yang sedang dalam himpitan ekonomi dan Rasulullah saw. telah menekankan bahwa kefakiran memiliki potensi pada kekafiran. Tentu saja kafir dalam konteks hadis tersebut tidak semata-mata bermakna mengingkari agama, namun kekafiran dapat bermakna pengingkaran warga Negara terhadap legitimasi pemerintahan dari rezim yang berkuasa.

\section{KESIMPULAN}

Sebagai Negara dengan mayoritas penduduk muslim, Indonesia dapat menjadi Negara yang rapuh dalam menghadapi pandemi. Ketika rezim berkuasa tidak lagi melakukan upaya maksimal untuk mendengarkan aspirasi rakyat dengan menempatkan MUI sebagai garda terdepan dalam merebut legitimasi rkyat dari sector agama, maka mungkin akan terjadi penurunan kepercayaan rakyat kepada pemerintah dan mengurangi legitimasinya. Mencontoh dari legitimasi rezim pemerintahan Islam dalam merebut hati rakyat ketika pandemi terjadi, rezim Jokowi hendak pula melakukan hal yang sama lantaran background keagamaan yang sama. Rezim pemerintahan Islam memelihara konteks bahasa agama untuk mempertahankan kekuasaan mereka sekaligus bangsa mereka.

Bercermin dari perilaku rezim pemerintahan Islam dalam mengambil hati rakyatnya, pemerintahan rezim Jokowi sebaiknya melakukan hal serupa agar riak dan gerakan melawan pemerintah dan upaya menarik legitimasi kekuasaan, tidak terjadi. 


\section{DAFTAR PUSTAKA}

A.J. Wensinck, Mu'jam Mufaḥ ras Li Alfāz al-Hadīs al-Nabawi (Leiden: E.J. Brill, 1936)

Abū 'Abdillāh Muḥammad bin Ismā'îl al-Bukhārī, "Al-Jāmi' al-Ṣaḥị̣ Li Abī 'Abdillāh Muḥammad bin Ismā'îl al-Bukhārī”' (Kairo: Maktabah al-Salafiyah, 1980)

Afifiyah, Sitti, "Pandemi Corona dan Kisah Wabah Penyakit Zaman Nabi," Tagar.id untuk Indonesia (Jakarta, 2020)

Akeel Bilgrami, Secularism, Identity, and Enchantment, 1st ed. (London: Harvard University Press, 2014)

Alyanak, Oğuz, "Faith, Politics and the COVID-19 Pandemic: The Turkish Response," Medical Anthropology: Cross Cultural Studies in Health and Illness, 00.00 (2020), 1-2 <https://doi.org/10.1080/01459740.2020.1745482>

Ashraf, Hamid, Ahmad Faraz, Md Raihan, dan Sanjay Kalra, "Fighting pandemics: Inspiration from Islam," JPMA. The Journal of the Pakistan Medical Association, 70 3).5 (2020), S152-56 <https://doi.org/10.5455/JPMA.34>

Conrad, Lawrence I, “Ta ' Un and W' Aba'," Social History, 25.3 (2013), 268-307

Darmawan, Dadang, Deni Miharja, Roro Sri Rejeki Waluyajati, dan Erni Isnaeniah, "Sikap Keberagamaan Masyarakat Menghadapi Wabah COVID19," Religious: Jurnal Studi Agama-Agama dan Lintas Budaya, 4.2 (2020), 115-24 $<$ https://doi.org/10.15575/rjsalb.v4i2.8596>

Elsa Catriana, "RI Dinilai Perlu Waspada Potensi Resesi Ekonomi Akibat Corona," Kompas.com (Jakarta, 2020) $<$ https://money.kompas.com/read/2020/03/19/162019026/ri-dinilai-perluwaspada-potensi-resesi-ekonomi-akibat-corona>

Encep Faiz, "Kisah Khulafaur Rasyidin Umar bin Khatab: Obat Penyakit Mematikan ada Pada Sabda Nabi," Mantra Sukabumi (Sukabumi, April 2020)

Firmansyah, Teguh, "No Title," Republika.co.id, 2020 <https://republika.co.id/berita/qcj7fa377/bamusi-pdip-bukan-komunis>

Gumilar Rusliwa Somantri, "MEMAHAMI METODE KUALITATIF," Makara, Sosial Humaniora, 9.2 (2005), 57-65

Hadi, Kisno, "LEGITIMASI KEKUASAAN DAN HUBUNGAN PENGUASARAKYAT DALAM PEMIKIRAN POLITIK SUKU DAYAK MA'ANYAN," Jurnal Kawistara, 8.1 (2018), 46 <https://doi.org/10.22146/kawistara.28082>

Kristo, Fino Yurio, "Pejabat China: COVID-19 Sudah Lama Ada, Bukan dari Pasar Wuhan," Detik.com, 2020

Kuru, Ahmet T, Secularism and State Policies Toward Religion The United States, France, and Turkey, ed. oleh Kenneth D. Wald David C. Leege, 1st ed. (New York: Cambridge University Press, 2009)

Michael W. Dols, "The Second Plague Pandemic And Its Recurrences In The Middle East: 1347-1894," Journal Of Economic and Social History of the Orient, 
22.2 (1979), 162-89

Muhammad Subarkah, "Deus Abscond: Penguasa Tersembunyi dari Pandemi COVID-19," Republika.co.id (Jakarta, 2020) $<$ https://republika.co.id/berita/qagl8k385/emdeus-abscondem-penguasatersembunyi-dari-pandemi-covid19>

"MUI Ajak Ormas Islam Dukung Kebijakan Jokowi Atasi Corona," CNN Indonesia, 2020

Mushodiq, Muhamad Agus, dan Ali Imron, "Peran Majelis Ulama Indonesia Dalam Mitigasi Pandemi Covid-19 (Tinjauan Tindakan Sosial dan Dominasi Kekuasaan Max Weber)," SALAM: Jurnal Sosial dan Budaya Syar-i, 7.5 (2020) $<$ https://doi.org/10.15408/sjsbs.v7i5.15315>

Nanda Perdana, "Berikut 9 Poin Fatwa MUI Sikapi Wabah Virus Corona di Indonesia," Merdeka.com (Jakarta, 2020)

Nur Azizah, "Mahfud Tanggapi Keluhan MUI Terkait Penutupan Masjid," medcom.id, 2020

Rayful Mudassir, "MUI Kritik Pemerintah Soal Penutupan Masjid," Bisnis.com, 2020

Saubani, Sapto Andika Candra/ Red: Andri, “Jokowi Umumkan Dua Kasus Pertama Positif Corona di Indonesia," Republika.co.id, 2020

Society, American Oriental, "Plague in Early Islamic History Author ( s ): Michael W . Dols Published by: American Oriental Society Stable URL: http://www.jstor.org/stable/600071 . PLAGUE IN EARLY ISLAMIC HISTORY," 94.3 (2013), 371-83

TB. Massa Djafar, “Covid 19 Ancam Legitimasi Kekuasaan Jokowi?,” telusur.co.id, 2020

Umar, Subehan Khalik, "Studi Kritis Terhadap Respon Majelis Ulama Indonesia (Mui) Tentang Pemanfaatan Media Sosial Dalam Bermuamalah," Al Daulah: Jurnal Hukum Pidana dan Ketatanegaraan, $7.1 \quad$ (2018), 39-50 <https://doi.org/10.24252/ad.v7i1.5463> 